\title{
UPAYA MENINGKATKAN AKURASI TEKNIK PASSING MENGGUNAKAN METODE DRILL PADA KEGIATAN EKSTRAKURIKULER SEPAKBOLA
}

\author{
Gustianto Irawan $^{1}$, Tatok Sugiarto ${ }^{2}$, Ari Wibowo Kurniawan ${ }^{3}$ \\ 1,2,3 Pendidikan Jasmani dan Kesehatan, Fakultas Ilmu Keolahragaan, \\ Universitas Negeri Malang
}

email: gustiantoirawan83@gmail.com

\begin{abstract}
Abstrak
Penelitian ini bertujuan untuk meningkatkan akurasi passing dengan metode drill pada kegiatan ekstrakulikuler SMPN 10 Malang. Penelitian ini menggunakan analisis data secara kuantitatif dengan metode penelitian tindakan olahraga (PTO), serta menggunakan instrumen berupa tes. Subjek penelitian adalah peserta ekstrakurikuler sepakbola SMPN 10 Malang yang terdiri dari 20 siswa laki - laki. Berdasarkan hasil penelitian dapat disimpulkan bahwa keterampilan passing kaki bagian dalam, kaki bagian luar dan passing kaki bagian punggung permainan sepakbola menunjukkan adanya peningkatan yang signifikan dengan penggunaan metode drill yaitu masuk pada pada kategori baik sekali.
\end{abstract}

Kata-kata kunci: sepakbola, passing, metode drill

\begin{abstract}
This study aims to improve the accuracy of passing with the drill method in extracurricular activities of Junior High School 10 Malang. This study uses quatitative data analysis with sport action research (PTO), and uses instrumens in the form of test. The research subjects were participants in football extracurricular activities at Junior High School 10 Malang consisting of 20 male students. Based on the results of the study it can be concluded that the passing skills of the inner leg, the outside of the foot and the passing of the back of the football game show a significant increase in entering the excellent category.
\end{abstract}

Keywords : football, passing, drill method

\section{PENDAHULUAN}

Kegiatan ekstrakurikuler olahraga merupakan program sekolah yang bertujuan untuk pembentukan nilai-nilai kepribadian para peserta didik melalui olahraga. Selain itu, Kegiatan ekstrakurikuler olahraga adalah suatu wadah bagi siswa di sekolah untuk mengembangkan bakat dan keterampilan di bidang olahraga sebagai pembinaan prestasi di bidang olahraga.

Sepakbola adalah salah satu kegiatan ekstrakurikuler yang diadakan di SMPN 10 Malang dengan jumlah peserta didik sebanyak 20 orang. Kegiatan ekstrakurikuler sepakbola dilaksanakan di lapangan SMPN 10 Malang pada hari Selasa dan Jum'at pada pukul 15.00-17.00 WIB. 
Untuk dapat mencapai tujuan bermain sepakbola yaitu meraih kemenangan dengan menciptakan gol lebih banyak dari kebobolan, maka pemain diharuskan menguasai teknik dasar sepakbola yang baik. Menurut Amiq (2016:6), "beberapa teknik dasar yang perlu dimiliki pemain sepakbola adalah menendang (shooting), menyundul (heading), menjaga gawang (goalkeeping), lemparan ke dalam (throw-in), dan mengumpan (passing). Passing dibagi menjadi 3 yaitu passing kaki bagian dalam, kaki bagian luar, dan passing kaki bagian punggung.

Metode drill adalah suatu cara mengajar di mana siswa melaksanakan kegiatan-kegiatan latihan, agar siswa memiliki keterampilan yang lebih baik dari sebelumnya. Menurut (Aprinova dan Hariadi, 2016:67) menjelaskan bahwa "Metode drill merupakan suatu metode latihan yang sesuai dengan masalah yang terjadi dikarenakan metode drill adalah salah satu metode untuk meningkatkan kesadaran tentang berbagai faktor yang berhubungan dengan gerak, yaitu kesadaran waktu, gaya dan ruang. Anak-anak diarahkan agar bisa merasakan cepat lambatnya gerakan, merasakan gaya yang menimbulkan dan menghambat gerakan, serta merasakan dirinya berada di dalam lingkungan ruang".

Sedangkan menurut (Syaifuddin dkk, 2017:274) menyatakan bahwa "latihan yang dilakukan secara berulang-ulang agar meningkatkan teknik tersebut dengan bertahap, karena dalam proses pembelajaran dapat memperoleh ketangkasan dalam meningkatkan keterampilan dan kemahiran dengan baik".

Menurut beberapa pendapat ahli di atas maka dapat disimpulkan metode drill adalah latihan yang dilakukan berulang-ulang untuk meningkatkan keterampilan gerak yang dapat membantu melakukan tantangan yang lebih baik. Penelitian ini menggunakan metodedrill. Pada penelitian ini ada 3 macam yaituwall pass, passing Give and Go, Passimaniacs. Wall pass adalah mengumpan bola ke teman yang berada di depan atau disamping tanpa menghentikan bola, biasanya dilakukan oleh 2 pemain.Passing give and go merupakan peluang bagi seorang pemain untuk melakukan passing kepada teman satu tim dan selanjutnya berlari ke depan, pemain yang menerima passing dengan cepat mengembalikan bola ke pemain pertama ketika mereka bersama-sama maju ke daerah lain di lapangan (mielke, 2007:24). Jadi passing give and go dilakukan dengan cara pemain mengoper bola ke pemain lainnya sambil berlari ke depan, kemudian pemain yang menerima bola mengembalikan dengan memantulkan lagi dengan satu sentuhan tanpa menghentikan bola. Permainan passimaniacs menggembangkan teknik passing yang tepat dan kontrol yang efektif dalam memberikan passing (Mielke, 2007:25). Permainan ini dilakukan dalam kotak yang berukuran $20 \mathrm{~m}$ x $20 \mathrm{~m}$. Permainan ini dilakukan oleh 7 pemain di masing-masing tim, dengan cara mempertahankan bola agar tidak tersentuh lawan. Salah satu tim dinyatakan menang apabila melakukan passing ke teman se tim sebanyak 10 kali tanpa tersentuh lawan.

Berdasarkan pengamatan saat tim sepakbola SMPN 10 Malang pada saat melakukan game. Dari hasil pengamatan tersebut peneliti dapat menemukan kelemahan pemain sepakbola SMPN 10 Malang yaitu pemain seringkali melakukan kesalahan pada teknik dasar passing, bahwa arah gerakan teknik passing peserta didik banyak yang masih tidak konsisten dan tidak teratur, masih ada arah passing 
yang melayang. Sementara itu, banyak peserta yang passingnya tidak terarah pada saat mengumpan bola dan pelan pada saat passing. Seharusnya, passing itu proses memindahkan bola dari satu pemain ke pemain lainnya. Setelah dilakukan wawancara peneliti dengan Bapak Sendika Septa Indrawanro sebagai pembina ekstrakurikuler sepakbola di SMPN 10 Malang terkait mengapa tim sepakbola SMPN 10 Malang Prestasinya menurun tidak dapat berprestasi bahkan tidak dapat menembus babak semifinal dalam berbagai kompetisi antar pelajar di Kota Malang, ternyata program latihan yang disajikan hanya terfokus pada materi latihan teknik dasar yang berupa shooting dan sesi latihan game. Materi latihan passing, kurang difokuskan dan tidak diberikan saat latihan dan pelatih tidak menyediakan program latihan secara terstruktur. Maka, pada saat bertanding pemain sering salah dalam mengoper ke teman sendiri dan permainan tidak berjalan dengan maksimal.

Dari hasil pengamatan di atas, peneliti melakukan tes awal untuk mengetahui keterampilan passing peserta ekstrakurikuler sepakbola SMPN 10 Malangpada hari Rabu tanggal 27 Februari 2019. Hasil tes keterampilan passing kaki bagian dalam jumlah peserta yang memperoleh kategori baik berjumlah 4 peserta (20\%), peserta yang memperoleh kategori cukup berjumlah 7 peserta (35\%), peserta yang memperoleh kategori kurang berjumlah 6 peserta $(30 \%)$, peserta yang memperoleh kategori kurang sekali berjumlah 3 peserta $(15 \%)$, dan tidak ada satupun peserta yang memperoleh kategori baik sekali, sementara passing kaki bagian luar jumlah peserta yang memperoleh kategori baik berjumlah 5 peserta (25\%), peserta yang memperoleh kategori cukup berjumlah 5 peserta (25\%),peserta yang memperoleh kategori kurang berjumlah 7 peserta (35\%), peserta yang memperoleh kategori kurang sekali berjumlah 3 peserta (15\%), dan tidak ada satupun peserta yang memperoleh kategori baik sekali, dan passing kaki bagian punggung jumlah peserta yang memperoleh kategori baik berjumlah 3 peserta (15\%), peserta yang memperoleh kategori cukup berjumlah 6 peserta (30\%), peserta yang memperoleh kategori kurang berjumlah 7 peserta (35\%), peserta yang memperoleh kategori kurang sekali berjumlah 4 peserta (20\%), dan tidak ada satupun peserta yang memperoleh kategori baik sekali. Dengan adanya pengamatan dan hasil tes tersebut peneliti menyimpulkan bahwa passing yang dimiliki oleh peserta ekstrakurikuler sepakbola SMPN 10 Malang perlu ditingkatkan melalui penelitian ilmiah. Latihan yang dapat diberikan untuk meningkatkan keterampilan passing peserta ekstrakurikuler sepakbola SMPN 10 Malang berupa latihan metode drill.

Berdasarkan uraian tersebut untuk meningkatkan keterampilan passing peserta ekstrakurikuler sepakbola SMPN 10 Malang, peneliti tertarik melakukan penelitian dengan mencoba memberi latihan berupa metode drill, maka disusunlah proposal penelitiann dengan judul "Upaya Meningkatkan Akurasi Passing dengan Metode Drill pada Peserta Ekstrakurikuler Sepakbola SMPN 10 Malang”.

\section{METODE PENELITIAN}

Berdasarkan tujuan dari penelitian ini, yaitu untuk meningkatkan Akurasi passing pada peserta ekstrakurikuler sepakbola SMPN 10 Malang dengan menggunakan metode 
drill, maka rancangan penelitian yang dipilih adalah penelitian tindakan olahraga. Subjek dalam penelitian ini adalah peserta ekstrakurikuler sepakbola SMPN 10 Malang dengan jumlah peserta 20 orang. Sumber data dalam penelitian ini adalah pelatih ekstrakurikuler sepakbola SMPN 10 Malang dan peserta ekstrakurikuler sepakbola SMPN 10 Malang sebanyak 20 orang dengan menggunakan lembar penilaian dan catatan lapangan. Menurut Tim UM (2010:59) "sumber data utama biasanya adalah peserta didik sebagai kumpulan individu atau kelompok, karena merekalah yang secara logis dan tradisional akan menampilkan perubahan yang terjadi akibat penerapan tindakan".

Secara operasional prosedur pengumpulan data yang dilakukan dalam penelitian ini pada tahap persiapan adalah sebagai berikut: (1) peneliti melakukan wawancara kepada pelatih ekstrakurikuler sepakbola SMPN 10 Malang yaitu Sendika Septa Indrawanro S.Pd dan pesertaekstrakurikuler sepakbola SMPN 10 Malang mengenai passing, pada tanggal 9 Oktober 2018, (2) melakukan observasi dengan melakukan tes Akurasi teknikpassing, (3) merumuskan masalah penelitian yang muncul, (4) mengajukan ijin melakukan penelitian tindakan olahraga, (5) menyusun proposal.

Setelah tahap persiapan dilakukan, langkah selanjutnya adalah tahap pelaksanaan. Pada tahap ini akan dilakukan: (1) perencanaan tindakan dengan pembuatan program latihan dan lembar penilaian, (2) pelaksanaan penelitian yang dilakukan pada tahun 2018-2019 di SMPN 10 Malang, (3) pelatih ekstrakurikuler sepakbola SMPN 10 Malangsebagai penyampai program latihan yang telah dibuat oleh peneliti, (4) setiap pertemuan, peneliti, pelatih melakukan refleksi terhadap hasil latihan yang telah dilakukan dan merumuskan perbaikan untuk pertemuan berikutnya.

Sesuai dengan tujuan penelitian ini, maka teknik analisis data menggunakan uji statistik deskriptif kualitatif dan deskriptif kuantitatif yang merupakan jenis analisis statistik yang bermaksud mendeskripsikan sifat-sifat sampel atau populasi dengan persentase. Menurut Sudijono (2008:43), rumus untuk mengolah data yang berupa deskriptif kuantitatif adalah sebagai berikut:

$$
\mathrm{P}=\mathrm{f} / \mathrm{N} \times 100 \%
$$

\section{Keterangan:}

$\mathrm{P} \quad=$ Angka Persentase.

$\mathrm{f} \quad=$ Frekuensi.

$\mathrm{N} \quad=$ Number of Class (jumlah frekuensi/banyaknya individu).

Menurut Arikunto dan Jabar (2010:35), sebagai acuan taraf keberhasilan tindakan dapat dilihat pada tabel 1 sebagai berikut.

Tabel 1 Persentase Taraf Keberhasilan Tindakan

\begin{tabular}{cc}
\hline Persentase Keberhasilan Tindakan & Taraf Keberhasilan \\
\hline $80-100 \%$ & Baik sekali \\
$66-79 \%$ & Baik \\
$56-65 \%$ & Cukup \\
$40-55 \%$ & Kurang Baik \\
$<40 \%$ & Kurang Sekali \\
\hline
\end{tabular}

(Sumber: Arikunto \& Jabar, 2010:35) 


\section{HASIL DAN PEMBAHASAN}

\section{Hasil}

Berdasarkan hasil observasi awal Pada hari rabu tanggal 27 Februari 2019 peneliti melakukan tes awal keterampilan passing kaki bagian dalam, kaki bagian luar dan passing kaki bagian punggung pada dinding. Hasil tes keterampilan passing kaki bagian dalam jumlah peserta yang memperoleh kategori baik berjumlah 4 peserta (20\%), peserta yang memperoleh kategori cukup berjumlah 7 peserta (35\%), peserta yang memperoleh kategori kurang berjumlah 6 peserta (30\%), peserta yang memperoleh kategori kurang sekali berjumlah 3 peserta (15\%), dan tidak ada satupun peserta yang memperoleh kategori baik sekali, sementara passing kaki bagian luar jumlah peserta yang memperoleh kategori baik berjumlah 5 peserta (25\%), peserta yang memperoleh kategori cukup berjumlah 5 peserta (25\%), peserta yang memperoleh kategori kurang berjumlah 7 peserta (35\%), peserta yang memperoleh kategori kurang sekali berjumlah 3 peserta (15\%), dan tidak ada satupun peserta yang memperoleh kategori baik sekali, dan passing kaki bagian punggung jumlah peserta yang memperoleh kategori baik berjumlah 3 peserta (15\%), peserta yang memperoleh kategori cukup berjumlah 6 peserta (30\%), peserta yang memperoleh kategori kurang berjumlah 7 peserta (35\%), peserta yang memperoleh kategori kurang sekali berjumlah 4 peserta (20\%), dan tidak ada satupun peserta yang memperoleh kategori baik sekali. Data hasil dari tes awal dipaparkan pada tabel sebagai berikut:

Tabel 2. Data Hasil Observasi Tes Peserta Ektrakurikuler Sepakbola di SMP Negeri 10 Malang

\begin{tabular}{lccc}
\hline \multirow{2}{*}{ Kategori } & \multicolumn{3}{c}{ Tes Keterampilan Passing Sepakbola } \\
\cline { 2 - 4 } & $\begin{array}{c}\text { Passing Kaki } \\
\text { Bagian Dalam }\end{array}$ & $\begin{array}{c}\text { Passing Kaki } \\
\text { Bagian Luar }\end{array}$ & $\begin{array}{c}\text { Passing Kaki } \\
\text { Bagian Punggung }\end{array}$ \\
\hline Baik sekali & $0 \%$ & $0 \%$ & $0 \%$ \\
Baik & $20 \%$ & $25 \%$ & $15 \%$ \\
Cukup & $35 \%$ & $25 \%$ & $30 \%$ \\
Kurang & $30 \%$ & $35 \%$ & $35 \%$ \\
Kurang sekali & $15 \%$ & $15 \%$ & $20 \%$ \\
\hline
\end{tabular}

\section{Siklus 1}

Setelah mengetahui tingkat kesulitan yang dialami oleh peserta dari hasil tes keterampilan awal, peneliti beserta pelatih mempersiapkan Rancangan Program Latihan (RPL) untuk materi latihan teknik Akurasi passing di SMPN 10 Malang untuk setiap pertemuan.

Kemudian melaksanakan latihann terkait dengan materi passing dengan menggunakan metode drill pada tanggal 1 Maret 2019 sampai dengan 26 Maret2019, dimana pada siklus 1 berlangsung selama 8 kali pertemuan. Hasil tindakan pada siklus 1 sudah cukup baik dan mengalami peningkatan yang cukup signifikan, dapat dilihat passing kaki bagian dalam memperoleh kategori baik sekali berjumlah 6 peserta (30\%), peserta yang memperoleh kategori baik berjumlah 11 peserta (55\%), peserta yang memperoleh kategori cukup berjumlah 2 peserta 
(10\%), peserta yang memperoleh kategori kurang berjumlah 1 peserta (5\%), dan tidak ada satupun peserta yang memperoleh kategori kurang sekali, sementara pada passing kaki bagian luar memperoleh kategori baik sekali berjumlah 5 peserta $(25 \%)$, peserta yang memperoleh kategori baik berjumlah 11 peserta (55\%), peserta yang memperoleh kategori cukup berjumlah 2 peserta (10\%), peserta yang memperoleh kategori kurang berjumlah 2 peserta (10\%), dan tidak ada satupun peserta yang memperoleh kategori kurang sekali, dan pada passing kaki bagian punggung memperoleh kategori baik sekali berjumlah 6 peserta (30\%), peserta yang memperoleh kategori baik berjumlah 10 peserta (50\%), peserta yang memperoleh kategori cukup berjumlah 2 peserta (10\%), peserta yang memperoleh kategori kurang berjumlah 2 peserta (10\%), dan tidak ada satupun peserta yang memperoleh kategori kurang sekali. Hasil dari siklus 1 dapat dilihat pada tabel sebagai berikut:

Tabel 3. Data Hasil Tes Akurasi Passing Permainan Sepakbola Pada Pertemuan Ke- 8 Siklus $1(n=20)$

\begin{tabular}{lccc}
\hline \multirow{2}{*}{ Kategori } & \multicolumn{3}{c}{ Tes Keterampilan Passing Sepakbola } \\
\cline { 2 - 4 } & $\begin{array}{c}\text { Passing Kaki } \\
\text { Bagian Dalam }\end{array}$ & $\begin{array}{c}\text { Passing Kaki } \\
\text { Bagian Luar }\end{array}$ & $\begin{array}{c}\text { Passing Kaki } \\
\text { Bagian Punggung }\end{array}$ \\
\hline Baik sekali & $30 \%$ & $25 \%$ & $30 \%$ \\
Baik & $55 \%$ & $55 \%$ & $50 \%$ \\
Cukup & $10 \%$ & $10 \%$ & $10 \%$ \\
Kurang & $5 \%$ & $10 \%$ & $10 \%$ \\
Kurang sekali & $0 \%$ & $0 \%$ & $0 \%$ \\
\hline
\end{tabular}

Berdasarkan hasil data mengenai tingkat keberhasilan peserta dalam melakukan latihan passing pada ekstrakurikuler sepakbola SMPN 10 Malang telah diperoleh hasil dari tindakan siklus 1 selama 4 minggu dan delapan kali pertemuan, pada passingtingkat keberhasilan persentasenya mencapai kategori cukup. Maka dapat disimpulkan bahwa tujuan dari penelitian ini sudah tercapai, akan tetapi peneliti masih perlu mengoptimalkan dan meningkatkan lagi Akurasi passing pada peserta ekstrakurikuler sepakbola SMPN 10 Malang, terutama pada peserta ekstrakurikuler sepakbola SMPN 10 Malang yang belum tuntas. Oleh karena itu peneliti melaksanakan tindakan lanjutan pada siklus 2 .

\section{Siklus 2}

Berdasarkan hasil evaluasi dan refleksi pada siklus 1 yang dilakukan peneliti dan pelatih, maka akan dilakukan latihan Akurasi passing menggunakan metode drill pada siklus 2. Peneliti mempersiapkan rencana pelaksanaan latihan pada siklus 2 untuk 8 kali pertemuan dalam 4 minggu dengan membuat program latihan.

Kemudian melaksanakan latihanterkait dengan materi akurasi passing dengan menggunakan metode drill pada tanggal 29 Maret 2019 sampai dengan 23 April 2019, dimana pada siklus 2 berlangsung selama 8 kali pertemuan. melakukan passing kaki bagian dalam memperoleh kategori baik sekali berjumlah17 peserta (85\%), peserta yang memperoleh kategori baik 
berjumlah 2 peserta (10\%), peserta yang memperoleh kategori cukup berjumlah 1 peserta (5\%), tidak ada satupun peserta yang memperoleh kategori kurang dan kurang sekali, sementara pada passing kaki bagian luar memperoleh kategori baik sekali berjumlah 14 peserta (70\%), peserta yang memperoleh kategori baik berjumlah 4 peserta (20\%), peserta yang memperoleh kategori cukup berjumlah 2 peserta (10\%), tidak ada satupun peserta yang memperoleh kategori kurang dan kurang sekali, dan pada passing kaki bagian punggung memperoleh kategori baik sekali berjumlah 15 peserta (75\%), peserta yang memperoleh kategori baik berjumlah 3 peserta (15\%), peserta yang memperoleh kategori cukup berjumlah 2 peserta (10\%), tidak ada satupun peserta yang memperoleh kategori kurang dan kurang sekali.Hasil dari siklus 2 dapat dilihat pada tabel sebagai berikut.

Tabel 4. Data Hasil Tes Akurasi Passing pada Pertemuan Ke-8 Siklus 2 (n=20)

\begin{tabular}{lccc}
\hline \multirow{2}{*}{ Kategori } & \multicolumn{3}{c}{ Tes Keterampilan Passing Sepakbola } \\
\cline { 2 - 4 } & $\begin{array}{c}\text { Passing Kaki } \\
\text { Bagian Dalam }\end{array}$ & $\begin{array}{c}\text { Passing Kaki } \\
\text { Bagian Luar }\end{array}$ & $\begin{array}{c}\text { Passing Kaki } \\
\text { Bagian Punggung }\end{array}$ \\
\hline Baik sekali & $85 \%$ & $70 \%$ & $75 \%$ \\
Baik & $10 \%$ & $20 \%$ & $15 \%$ \\
Cukup & $5 \%$ & $10 \%$ & $10 \%$ \\
Kurang & $0 \%$ & $0 \%$ & $0 \%$ \\
Kurang sekali & $0 \%$ & $0 \%$ & $0 \%$ \\
\hline
\end{tabular}

Karena tingkat keberhasilan dari teknik akurasi passing sudah mencapai kriteria yang diharapkan, maka tindakan pada siklus 2 untuk meningkatkan akurasi passingpadapeserta ekstrakurikuler sepakbola SMPN 10 Malang, pelatih dan peneliti memutuskan untuk menghentikan tindakan sampai pada siklus 2 .

\section{Pembahasan}

Peneliti melakukan observasi awal pada kegiatan ekstrakurikuler sepakbola SMP Negeri 10 Malang dan mendapatkan hasil bahwa keterampilan teknik dasar passing pada peserta ekstrakurikuler sepakbola perlu untuk ditingkatkan. Sebelum menerapkan program latihan untuk meningkatkan akurasi teknik dasar passing kaki bagian dalam, kaki bagian luar dan passing kaki bagian punggung permainan sepakbola, peneliti mencoba untuk mengetahui tingkat prestasi passing kaki bagian dalam, kaki bagian luar dan passing kaki bagian punggung pada peserta ekstrakurikuler sepakbola SMP Negeri 10 Malang melalui tes passing pada dinding selama 30 detik dengan 2 kali pengulangan. Berdasarkan hasil tes keterampilan awal diperoleh hasil bahwa tingkat hasil tes keterampilan passing kaki bagian dalam jumlah peserta yang memperoleh kategori baik berjumlah 4 peserta (20\%), peserta yang memperoleh kategori cukup berjumlah 7 peserta (35\%), peserta yang memperoleh kategori kurang berjumlah 6 peserta (30\%), peserta yang memperoleh kategori kurang sekali berjumlah 3 peserta (15\%), dan tidak ada satupun peserta yang memperoleh kategori baik sekali, sementara passing kaki bagian luar jumlah peserta yang memperoleh kategori baik berjumlah 5 peserta (25\%), peserta yang memperoleh 
kategori cukup berjumlah 5 peserta (25\%), peserta yang memperoleh kategori kurang berjumlah 7 peserta (35\%), peserta yang memperoleh kategori kurang sekali berjumlah 3 peserta $(15 \%)$, dan tidak ada satupun peserta yang memperoleh kategori baik sekali, dan passing kaki bagian punggung jumlah peserta yang memperoleh kategori baik berjumlah 3 peserta (15\%), peserta yang memperoleh kategori cukup berjumlah 6 peserta (30\%), peserta yang memperoleh kategori kurang berjumlah 7 peserta (35\%), peserta yang memperoleh kategori kurang sekali berjumlah 4 peserta (20\%), dan tidak ada satupun peserta yang memperoleh kategori baik sekali.Untuk itu peneliti melakukan tindakan guna untuk meningkatkan keterampilan passing kaki bagian dalam, kaki bagian luar dan passing kaki bagian punggung permainan sepakbola menggunakan metode drill.

Pada saat melakukan penelitian, pelaksanaan latihan siklus 1 dilakukan selama 4 minggu dengan 8 kali pertemuan. Pada minggu ke-4 pertemuan 8 , peneliti memberikan tes keterampilan passing kaki bagian dalam, kaki bagian luar dan passing kaki bagian punggung pada dinding. Data yang diperoleh dari tes passing kaki bagian dalam memperoleh kategori baik sekali berjumlah 6 peserta $(30 \%)$, peserta yang memperoleh kategori baik berjumlah 11 peserta $(55 \%)$, peserta yang memperoleh kategori cukup berjumlah 2 peserta (10\%), peserta yang memperoleh kategori kurang berjumlah 1 peserta (5\%), dan tidak ada satupun peserta yang memperoleh kategori kurang sekali, sementara pada passing kaki bagian luar memperoleh kategori baik sekali berjumlah 5 peserta (25\%), peserta yang memperoleh kategori baik berjumlah 11 peserta
(55\%), peserta yang memperoleh kategori cukup berjumlah 2 peserta (10\%), peserta yang memperoleh kategori kurang berjumlah 2 peserta (10\%), dan tidak ada satupun peserta yang memperoleh kategori kurang sekali, dan pada passing kaki bagian punggung memperoleh kategori baik sekali berjumlah 6 peserta $(30 \%)$, peserta yang memperoleh kategori baik berjumlah 10 peserta $(50 \%)$, peserta yang memperoleh kategori cukup berjumlah 2 peserta (10\%), peserta yang memperoleh kategori kurang berjumlah 2 peserta (10\%), dan tidak ada satupun peserta yang memperoleh kategori kurang sekali. Berdasarkan data tersebut dapat disimpulkan bahwa keterampilan passing kaki bagian dalam, kaki bagian luar dan passing kaki bagian punggung peserta sudah meningkat. Namun peneliti melanjutkan penelitian pada siklus 2 karena masih ada peserta yang mendapatkan kategori kurang baik.

Pelaksanaan siklus 2 dilakukan selama 4 minggu dengan 8 kali pertemuan. Setelah pelaksanaan siklus 2 dilakukan tes keterampilan passing kaki bagian dalam, kaki bagian luar dan passing kaki bagian punggung yang digunakan sebagai hasil hasil akhir dari keberhasilan tindakan yang dilakukan. Pada minggu ke-4 pertemuan ke-8, peneliti memberikan tes keterampilan passing kaki bagian dalam, kaki bagian luar dan passing kaki bagian punggung pada dinding. Data yang diperoleh pada tes passing kaki bagian dalam memperoleh kategori baik sekali berjumlah 17 peserta (85\%), peserta yang memperoleh kategori baik berjumlah 2 peserta (10\%), peserta yang memperoleh kategori cukup berjumlah 1 peserta (5\%), tidak ada satupun peserta yang memperoleh kategori kurang dan kurang sekali, sementara pada passing kaki bagian 
luar memperoleh kategori baik sekali berjumlah 14 peserta (70\%), peserta yang memperoleh kategori baik berjumlah 4 peserta (20\%), peserta yang memperoleh kategori cukup berjumlah 2 peserta (10\%), tidak ada satupun peserta yang memperoleh kategori kurang dan kurang sekali, dan pada passing kaki bagian punggung memperoleh kategori baik sekali berjumlah 15 peserta (75\%), peserta yang memperoleh kategori baik berjumlah 3 peserta (15\%), peserta yang memperoleh kategori cukup berjumlah 2 peserta (10\%), tidak ada satupun peserta yang memperoleh kategori kurang dan kurang sekali.

Berdasarkan keseluruhan data yang telah diperoleh menunjukkan bahwa keterampilan teknik dasar passing kaki bagian dalam, kaki bagian luar dan passing kaki bagian punggung permainan sepakbola peserta ekstrakurikuler sepakbola SMP Negeri 10 Malang mengalami peningkatan. Berdasarkan hasil penelitian pada siklus 1 dan siklus 2 tentang penerapan metode drill pada teknik passing permainan sepakbola sudah mengalami peningkatan yang signifikan yaitu sudah banyak peserta yang masuk kategori sangat baik. Peningkatan keterampilan passing kaki bagian dalam, kaki bagian luar dan passing kaki bagian punggung permainan sepakbola dengan menggunakan metode drill ini sudah sesuai untuk diterapkan karena berdasarkan data yang diambil di lapangan telah menunjukkan perubahan serta peningkatan dari masalah yang telah ditemukan pada keterampilan teknik dasar passing permainan sepakbola. Dengan diterapkannya metode drill ini dapat dikategorikan berhasil dalam memecahkan masalah yang diangkat dalam penelitian ini. Karena persentase keberhasilan peserta pada saat mengikuti tes mengalami peningkatan, peneliti merasa cukup untuk melakukan penerapan latihan metode drill, sehingga peneliti menghentikan proses penelitian pada siklus 2 minggu keempat.

Berdasarkan hal tersebut dapat disimpulkan bahwa penerapan metode drill dapat meningkatkan akurasi passsing pada peserta ekstrakurikuler sepakbola SMPN 10 Malang. Metode drill yaitu suatu cara menyampaikan materi pelajaran untuk menanamkan kebiasaan kebiasaan tertentu. Juga, sebagai sarana untuk memelihara kebiasaan kebiasaan yang baik.Latihan merupakan proses yang berulang dan meningkat guna meningkatkan potensi dalam rangka mencapai prestasi yang maksimal, atlet mengikuti program latihan jangka panjang untuk meningkatkan kondisi jiwa dan raga untuk berkompetisi dalam sebuah penampilan (Tangkudung, 2012). Penelitian mengenai penggunaan metode latihan drill pernah diteliti oleh Darussalam (2018) yang menemukan bahwa metode latihan drill berpengaruh terhadap kemampuan teknik dasar passing sepakbola siswa SSB Sheva Sukakersa. Hasil penelitian menunjukkan terjadi peningkatkan kemampuan sebelum dan sesuah penggunaan metode latihan drill sebesar 2,1. Penelitian sejenis juga dilakukan oleh Rivai (2019) yang menunjukkan bahwa terjadi peningkatan rata-rata sebesar 2,48 poin dari sebelumnya (prestest $)=17$ poin menjadi 19,48 poin pada post-test atau terjadi peningkatan persentasi kemampuan belajar passing sebesar $15 \%$ pada peserta didik ekstrakurikuler sepakbola SMA Negeri 8 Pontianak.

\section{SIMPULAN DAN SARAN Simpulan}

Dari hasil data yang diperoleh pada semua tindakan yang telah 
dilakukan pada siklus 1 dan 2, maka dapat disimpulkan bahwa metode drill dapat meningkatkan akurasi passing pada peserta ekstrakurikuler sepakbola SMPN 10 Malang.

\section{Saran}

Berdasarkan hasil penelitian yang diperoleh, maka pada kesempatan ini peneliti bermaksud menyampaikan masukan atau saran sehubungan dengan harapan peneliti agar nantinya penelitian ini memiliki manfaat yang berguna bagi banyak orang, maka saran yang dapat diberikan adalah:

1. Metode drill dapat digunakan sebagai metode latihan akurasi passing pada peserta ekstrakurikuler sepakbola SMPN 10 Malang,

2. Penerapan latihan menggunakan metodedrill sebaiknya dapat diterapkan pada latihan yang lain dengan permasalahan yang sama agar lebih meningkat dan membaik.

\section{DAFTAR PUSTAKA}

Al Anshar, D. 2018. Pengaruh Metode Drill Terhadap Kemampuan Teknik Dasar Passing Sepakbola Siswa Sekolah Sepakbola (Ssb) Sheva Sukakersa.

Amiq, F. 2014. FUTSAL (Sejarah, Teknik Dasar, Persiapan Fisik, Strategi, dan Peraturan Permainan). Malang: Universitas Negeri Malang.

Amiq, F. 2016. Sepakbola (Sejarah Perkembangan, Teknik Dasar, Persiapan Kondisi Fisik, Peraturan Permainan, Dan
Strategi Bermain). Malang: Universitas Negeri Malang.

Aprinova. F. \& Hariadi. I. 2016.Metode Meningkatkan Teknik Dasar Menggiring Bola (Dribbling) Dalam Permainan Sepakbola Pada Siswa Sekolah Sepakbola Putra Zodiac Kabupaten Bojonegoro Usia 13-15 Tahun. Jurnal Kepelatihan Olahraga, Vol 1 No 1 Oktober 2016. (Online)

journal.um.ac.id/index.php/jko/a rticle/view/7709.

Rivai, M., Atiq, A., \& Triansyah, A. PENGARUH METODE

LATIHAN DRILL

TERHADAP

KETERAMPILAN PASSING

SEPAKBOLA PADA

PESERTA DIDIK

EKSTRAKURIKULER DI

SMA NEGERI 8

PONTIANAK. Jurnal

Pendidikan dan

Pembelajaran, 8(3).

Sudijono, Anas. 2008. Pengantar Statistik Pendidikan. Jakarta: PT. Raja Grafindo Persada.

Tangkudung, J. dan Puspitorini, W. 2012. Kepelatihan Olahraga;Pembinaan Prestasi Olahraga Edisi II. Jakarta: Cerdas Jaya. Arikunto, S. \& Jabar, C.SA. 2010. Evaluasi Program Pendidikan. Jakarta:Bumi Aksara 